\title{
PRIMARY ORAL MUCOSAL MELANOMAS - TWO CASE REPORTS AND COMPREHENSIVE LITERATURE REVIEW
}

\author{
Berislav Topić $^{1}$ Tarik Mašićz , Svjetlana Radović ${ }^{3}$, Ivor Lincender ${ }^{2}$ and Edin Muhić ${ }^{4}$ \\ ${ }^{1}$ Academy of Sciences and Arts of Bosnia and Herzegovina; ${ }^{2}$ Clinical Department of Maxillofacial Surgery, \\ Sarajevo University Hospital Centre, University of Sarajevo; ${ }^{3}$ Pathology Institute, School of Medicine, \\ University of Sarajevo; ${ }^{4}$ Private Dental Surgery, Sarajevo, Bosnia and Herzegovina
}

\begin{abstract}
SUMMARY - Oral melanoma (OM) occurs from activated or genetically altered epidermal melanocytes. There is no scientific evidence that $\mathrm{OM}$ can be linked to physical, chemical and thermal irritation, or to other risk factors of the oral cavity. According to figures from various countries, OM accounts for $0.2 \%$ to $7.5 \%$ (Japan) of all cases of melanoma of the skin and mucous membrane. The male to female ratio of OM is $2: 1$. About $80 \%$ of OMs are located in the mucosa of the palate and maxillary gingiva. This paper presents two cases of oral mucosal melanoma of the upper and lower lips in women aged 62 and 59 years. Diagnosis, differential diagnosis and therapy are reported.
\end{abstract}

Key words: Melanoma - pathology; Mouth neoplasms - diagnosis; Mouth neoplasms - therapy; Case reports

\section{Introduction}

Melanoma as a malignant lesion can occur from activated or genetically altered epidermal melanocytes. Activation of melanocytes is a result of complex interactions among genetic, constitutional and environmental factors ${ }^{1}$. In contrast to skin melanoma, the etiology of which in most cases is related to ultraviolet light, this risk factor does not exist for oral melanoma (OM). There is no scientific evidence that $\mathrm{OM}$ can be linked to physical, chemical and thermal irritation, or to other risk factors in the oral cavity, for example, alcohol, poor oral hygiene, caries and damaged teeth, prosthetics and other irritations to which oral cavity is constantly exposed. Formaldehyde and smoking are listed as risk factors. In workers professionally exposed to formaldehyde fumes, cases of sinonasal melanomas have been reported ${ }^{2}$. Swedish authors mention the

Correspondence to: Academician Berislav Topic, Academy of Sciences and Arts of Bosnia and Herzegovina, Bistrik 7, 70000 Sarajevo, Bosnia and Herzegovina

E-mail: topicberislav@gmail.com

Received November 18, 2016, accepted February 1, 2017 more prevalent pigmentation of oral mucosa in smokers, deeming it to be a risk factor for $\mathrm{OM}^{3}$. Knowledge of the etiology of OM comes mainly from epidemiological studies, but these risk factors for OM have not been confirmed by scientific evidence. It is thought that after dysplastic nevus, as a precursor, some OMs occur de novo ${ }^{4}$. The physiological accumulation of melanin pigmentation in melanocytes is manifested clinically in a variety of efflorescence on the skin, mainly moles and freckles. When melanin is formed and accumulated in melanocytes with malignant characteristics, melanomas occur. Melanomas may develop from preexisting pigmentation of the skin and mucosa, but some occur de novo.

For melanomas of the head and neck, Virag lists three types and gives their quantification ${ }^{5}$. They are: superficial spreading melanoma (SSM), which occurs in about $70 \%$ of patients; nodular malignant melanoma (NM), which occurs in about $15 \%$ of patients; and lentigo maligna melanoma (LMM), which occurs in about $15 \%$, in older patients, on the exposed parts of the body on the basis of premalignant melanosis as the result of chronic exposure to sunlight; according to the personal 
clinical experience of Professor Virag, acral melanomas do not occur on the skin of the head and neck 5 .

Melanomas of the skin are located in the area of the face and the front of the hair, accounting for most melanomas of the face and neck, and are related to lymph nodes in the parotid region ${ }^{6}$. In the superficial lobe of the parotid gland, there are 2 to $10 \mathrm{lymph}$ nodes, but half as many nodes lie medially to the facial nerve. Surgery of the parotid gland is complicated by the facial nerve and its branches (pes anserinus). Surgery of the parotid is said to be in fact surgery of the facial nerve ${ }^{7}$. Facial nerve has an important functional, aesthetic, operational, communication and social value.

The microscopic spread of melanoma develops in two directions, i.e. horizontally, radially (mainly related to the epidermis), and vertically, invasively (related to deeper structure of the skin and mucosa, dermis, subcutis, blood and lymph vessels) ${ }^{8}$.

The degree of invasiveness of a skin melanoma is determined histopathologically, using the Breslow ${ }^{9}$ or Clark ${ }^{10}$ criteria.

Breslow proposees direct measurement of tumor thickness using calibrated ocular micrometer. The maximum vertical diameter of the tumor is evaluated, which represents the distance from the tip of the granulated layer of the epidermis and deepest point of tumor cell infiltration, and if the lesion is ulcerated, then from the base of the ulcer to the deepest point of tumor invasion. According to this criterion, there are 4 stages of invasiveness 9 . The Clark criteria have five stages of invasiveness ${ }^{10}$.

\section{Characteristics of Oral Melanomas}

In contrast to the skin, it is more difficult to differentiate by microscope the papillary layer from the reticular layer in the oral mucosa, which means that the Clark criteria are not applicable for oral mucosa. Routine diagnostics of the depth or thickness of tumors, as defined by Clark and Breslow, has not been accepted in everyday practice for OM, due to these structural differences between the skin and the oral mucosa. For example, five-year survival with gingival melanoma was $18 \%$, and with melanoma of the palatal mucosa $11 \%{ }^{11}$. Most melanomas of the mucosa of the head and neck at the time when they are presented, are in stage I. Prasad et al..$^{12}$ defined this status using a 3-level micro-staging system, which represents differ- ent micro-anatomic spaces of the separate tissue barriers. These are a significant predictor related to 5-year survival $^{12,13}$. The American Joint Committee on Cancer (AJCC) Melanoma Staging Committee, in its already existing guide to melanoma, updated the criteria in the final version of the Tumor-Node-Metastasis (TNM) classification of melanoma ${ }^{14}$. However, in this updated version of the TNM classification of melanomas, the AJCC did not define criteria for mucosal melanomas because no universal staging system exists for them. Different staging systems are in use for different anatomic locations ${ }^{15}$. In the assessment of oral mucosal melanomas, a simplified system is used including three stages, as follows: stage I, primary localization of disease; stage II, primary disease with metastasis to cervical lymph nodes; and stage III, distant metastasis ${ }^{8}$.

As already mentioned, in stage I, a 3-level microstaging system has been defined, where each level represents a micro-anatomic space, defined by tissue boundary. Destruction of any barrier (boundary) of that space correlates with progressive deterioration of survival rates. Stage I has 3 levels: Level 1, in situ mucosal melanoma or microinvasion: Level 2, invasion restricted to the lamina propria; and Level 3, melanoma with deep invasion into the neighboring tissue, such as bone (in the oral mucosa), cartilage (in the larynx), or skeletal muscle $\mathrm{e}^{12,13}$.

The superficial architecture of oral melanomas is seen in macular, ulcerous or nodular forms.

According to the recommendation by the Western Society of Teachers of Oral Pathology (WESTOP) Banff Workshop, oral malignant melanomas should be considered separately from skin melanomas and subclassified according to the histopathologic picture as in situ melanomas; invasive melanomas; combined: invasive melanomas with in situ components; and atypical melanocyte proliferation, in cases where there is an equivocal histologic diagnosis ${ }^{16}$.

Japanese and Mexican authors suggest that $\mathrm{OM}$ differs from skin melanoma from the point of view of the clinical picture, etiology and malignancy. They propose 5 types of $\mathrm{OM}$ for the clinical picture: pigmented nodular type; non-pigmented nodular type; pigmented macular type; pigmented mixed type; and non-pigmented mixed type ${ }^{17,18}$.

Clinical verification of $\mathrm{OM}$ meets the $\mathrm{ABCDE}$ rules from the Anglo-Saxon and German dermatology literature: A, asymmetry; B, border irregularity; C, 
color variation; $\mathrm{D}$, diameter $>6 \mathrm{~mm}$; and $\mathrm{E}$, elevation $^{19-21}$.

This typical clinical characterization of melanomas has been extended by Šitum et al. ${ }^{22}$ from ABCDE to $\mathrm{ABCDEFG}$, which is used in professional work and self-examinations. ABCDE have the same characteristic as above, followed by: F, feeling, itch, burn or pain; and $\mathrm{G}$, growth, increasing size ${ }^{22}$.

A combination of these signs and symptoms arouses suspicion of a melanoma. It would be desirable to use characteristics in a flier, with photographs for health education related to suspicion of melanomas.

Oral melanomas begin in the early phases as patchy brown or black blisters of irregular shape, which grow or develop into diffuse or nodular formations with focal points in hyper- and hypopigmentation, ulceration, bleeding, pain or loss of teeth (gingival location). Spotty or satellite lesions may appear around an OM, as on the $\operatorname{skin}^{23-25}$. They are a sign of already advanced melanoma, and are often accompanied by metastases to cervical lymph nodes. Melanomas of the oral cavity are located in $80 \%$ of cases on the mucosa of the palate and gingiva, and in other parts of the oral cavity, e.g., buccal mucosa, lips, tongue, base of the mouth, and uvula in $20 \%$ of cases ${ }^{4,26,27}$. From $35 \%$ to $37 \%$ of patients in whom OM develops, have pre-existing benign melanomatosis of the oral mucosa ${ }^{28}$. The presence of asymptomatic oral pigmentation at the site of an $\mathrm{OM}$ is on average discovered before diagnosis, in onethird of patients. These asymptomatic pigmentations may be the beginning of the radial phase of development of a tumor and are often unrecognized by the physician and patient. This phase may last for months or even years, until the signs of a tumor or tumor invasion appear. The absence of problems frequently causes patients to delay seeking medical care ${ }^{29}$.

\section{Differential Diagnosis of Oral Melanomas}

Pigmentations of oral mucosa in terms of morphology may be solitary (focal), multiple or diffuse, and in terms of origin they are non-melanocytic and melanocytic ${ }^{30}$. Non-melanocytic pigmentations are tattoos, amalgam, medicament, heavy metals, lingua villosa nigra, and hemochromatosis. Melanocytic pigmentations are physiological (racial), ephelides (spots), smoker's melanosis, in systemic diseases, oral melanotic macule and palpable pigmented lesions (oral ma- lanoacanthoma, nevi - moles and oral malignant melanomas). Amelanotic oral melanomas are a particular problem, that is melanomas that occur de novo' ${ }^{29}$.

\section{Methods in the Diagnosis of Melanomas}

After a detailed family and personal history is taken, a very thorough clinical examination is conducted. Every pigmented change of the oral mucosa for which the precise cause is not known is suspect in terms of differential diagnosis for potential melanoma, and it must be diagnosed by histopathology. Histopathologic diagnosis is the gold standard in the diagnosis of melanomas.

Morphological examination of biopsy samples, stained using the standard hematoxylin-eosin (HE) method, is essential for setting the histopathologic diagnosis. The parameters evaluated by microscope include assessment of the following: presence of absence of melanocytes in the tumor (melanocytic or non-melanocytic tumor); cell morphology (epithelioid, spindle, plasmacytoid or mixed); form of cell organization (solid, alveolar, organoid or pagetoid); presence of necrosis, and perineural and perivascular invasion; and depth of tumor invasion, cell invasion according to the criteria of Prasad et al. ${ }^{12}$ divided into: (a) noninvasive (in situ), (b) microinvasive (first level in which tumor cells are present in the superficial part of lamina propria), (c) invasive (second level with tumor cells in the lamina propria), and (d) deeply invasive (third level where the invasion extends into the muscle, bone or cartilage).

Oral melanoma is a relatively rare neoplasm with poor prognosis, and the non-melanocytic type has even worse prognosis, in view of the fact that it is biologically more aggressive and harder to diagnose, which makes treatment of lesions more often prolonged. Conventional morphological analysis in many cases is not sufficient, and it is complemented with some other techniques, such as histochemistry (e.g., Periodic Acid Schiff (PAS) and Fontana stains) and more recently immunohistochemistry (IHC). IHC is a diagnostic method that is today widely used in histopathology, in view of its diagnostic, prognostic, and recently also theranostic importance. IHC allows visualization of specific cell or tissue macromolecules from the globulin group (designated as immunoglobins, antigens or immunogens). The antigen-antibody reac- 
tion, which is the basis of immunology, has found wide application in this method, which is performed in situ in human cells or tissues. The basis of this method is mutual affinity between antigens (epitope) and antibodies (paratope). The reaction is reversible because it is not based on the creation of chemical bonds. Visualization of the Ag-At bond is made using staining, that is, a chromogen, which does not change the biologic activity of the antibody. The most frequently used chromogen is 3,3'-diaminobenzedine (DAB) which stains the end product of the reaction brown, or 3-amino-9-ethylcarbazole which gives the end product of the reaction a red color.

Alongside IHC there is routine histopathologic diagnosis, molecular pathology methods are also used, which still cannot replace traditional morphological analysis, but can make significant contribution to correct establishment of the definitive histopathologic diagnosis.

Since OM cells may have an extremely polymorphic appearance (epithelioid, spindle or plasmocytoid) and this type of malignoma shows a wide morphological spectrum, and lesions may resemble epithelial, histologic, mesenchymal and neural tumors, the use of IHC in establishing definitive diagnosis is of great assistance. The most frequently used antibodies that react with melanocyte proteins are HMB-45, Melan A and protein $\mathrm{S}-100$. HMB- 45 is a $35-\mathrm{kDa}$ glycoprotein melanosome and is a marker of activated melanocytes, so it is used in the diagnosis of melanomas. It is a very sensitive, but slightly less specific melanocyte marker, in view of the fact that it sometimes shows expression in some other cell types. It can show zonal intra-tumor variations in the intensity of staining.

The Melan-A protein is a product of the MART-1 gene and is specific for melanocyte cells, and thus also for the lesions which develop from them. It is also a less specific protein, in view of the fact that it is also found in some other cell types, that is, benign and malignant tumors of the adrenocortical region, tumors of the testicles with their origin in Leydig cells, as well as ovarian tumors originating from Sertoli and Leydig cells.

Protein S-100 is a $21-\mathrm{kD}$ a protein of high sensitivity (97\%-100\%) and less specificity for melanocytes, since its expression is possible in lipocytes, chondrocytes, macrophages, and Langerhans and dendritic cells. Reduction in expression or loss of expression may occur in the zones of melanoma with strong necrosis. Protein S-100, besides helping in determining tumor thickness, has been shown in some studies to be of a potential prognostic value, i.e. the intensity of staining by protein S-100 was in reverse correlation with the survival time ${ }^{31-33}$.

All these routinely and most frequently used antibodies in the histopathologic diagnosis of $\mathrm{OM}$ are used in cases of melanocytic differentiation of tumor cells, i.e. in differentiating melanocytes from some other types of non-melanocytic malignant cells they resemble (e.g., cells of undifferentiated carcinomas, lymphomas), in visualization of occult tumor cells, assessment of the depth of tumor invasion, and in detection of metastasis. IHC is useful in the assessment of distribution-density, number and cytoarchitecture (degree of atypia) of the lines of the lesion.

Immunohistochemistry is not an absolutely sovereign diagnostic method; it is a very good auxiliary method, which is used abundantly in routine, especially in oncologic diagnosis. It cannot and must not replace traditional morphological diagnosis. IHC is an important but not obligatory diagnostic procedure. Immunohistochemical and molecular pathology methods are also used, which still cannot replace traditional morphological analysis, but can make significant contribution to correct establishment of the definitive histopathologic diagnosis.

In the diagnosis of OM, the following may also be used: computed tomography (CT); magnetic resonance imaging (MRI); and positron emission tomography (PET) which can hardly differentiate melanoma from nevus, but in combination of PET/CT it has diagnostic value ${ }^{8}$.

\section{Treatment of Melanomas}

Treatment of OM primarily presumes surgical removal of the tumor, with or without neck dissection. That is to say, the region of the head is the anatomically most complex part of the human body, where in a small area there are vital organs, osteomuscular and blood vessel structures, and nerves, but no less important is to point out that in this region there is the most dense network of lymphatic vessels and the greatest number of lymph nodes. Due to the latter, the possibility of metastasis of melanoma localized on the head (and mucosa) is also greater than on the skin of the 
body. Moreover, this fact is important in planning surgical procedure. It is no less important to point out that it is also a prominent localization, where the extent of the intervention involves mutilation and malformations that cannot be concealed. The skill of the surgeon, good planning of the procedure, and surgical technique are extremely important, not only for therapeutic reason, but also for the patient quality of life ${ }^{34}$.

Treatment of OM consists of surgical removal of the tumor, with or without neck dissection.

Adjuvant therapy is also administered, which includes radiotherapy, chemotherapy, immunotherapy and immunomodulators ${ }^{35}$.

\section{Case Report 1}

The patient B. E., a female aged 62, was admitted to the Clinical Department of Maxillofacial Surgery, Sarajevo University Hospital Centre, on April 16, 2007, due to tumorous changes in the region of the upper lip. The changes had been present for the previous 6 months as verrucous lesions and darker pigmentation, which were painless, with a tendency for gradual growth, and occasional spontaneous bleeding (Fig. 1). Her detailed medical history included no previous hospitalization, hereditary ailments, or allergies to food or medication. She took Lopril $1 \times 5 \mathrm{mg}$ as therapy and Apaurin when necessary. She was a nonsmoker, and did not consume alcohol. Clinical examination verified melanocytic changes localized on the mucosa, also affecting the angular part of the upper lip in the medial line, $2.5 \times 2.5 \mathrm{~cm}$ in diameter, with regular edges,

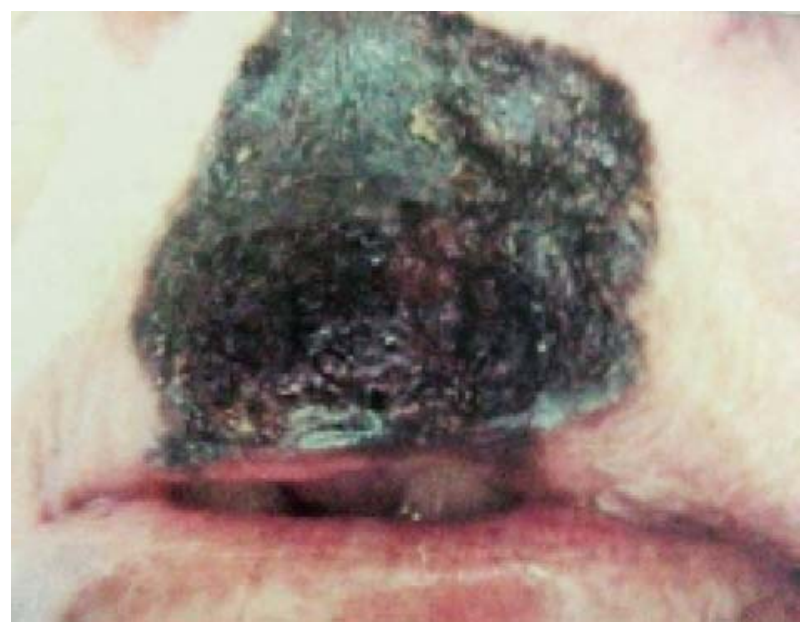

Fig. 1. Mucosal melanoma of the upper lip. slightly raised above the level of the surrounding mucosa and skin. The regional lymph nodes were not palpable. Surgical excision of the changes and primary reconstruction of the defect using a localized flap was performed. The histopathology results indicated Melanoma nodulare malignum mucosae labii superior (Clark 4, Breslow $1.7 \mathrm{~mm}, \mathrm{~T} 2 \mathrm{~b}$ ). After this, the patient was followed-up by the oncology consultant with regular examinations of the neck, abdomen and lung x-ray every six months.

In September 2011, due to bilateral neck lymphadenopathy, the patient was admitted to the hospital again. Bilateral supraomohyoid neck dissection was performed, and the histopathology results indicated regional dissemination of the disease. As part of the oncologic treatment, chemotherapy was administered (DTIC, dacarbazine), and the patient refused the proposed radiation treatment. The patient died on January 26, 2012.

\section{Case Report 2}

The patient M. A., a 59-year-old female, was admitted to the Clinical Department of Maxillofacial

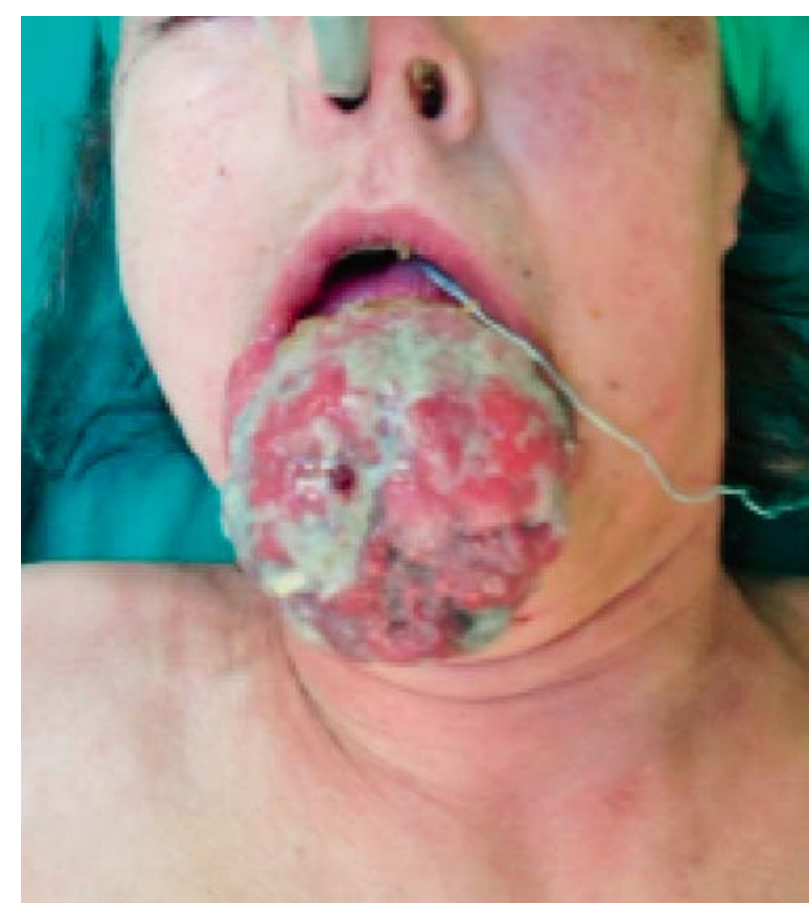

Fig. 2. Clinical appearance of a tumor on the mucosa of the lower lip at the time of patient admission to the hospital. 
Surgery, Sarajevo University Hospital Centre, on September 29, 2014, for extensive tumorous changes in the region of the lower lip. The changes had been present for several years as a small red nodule on the mucosa of the lower lip, with gradual growth (Fig. 2). The patient was a long-term neuropsychiatric patient with the diagnosis of schizophrenia. Her therapy included Haldol 2x2 mg, Trazem 1x1, Prazine 1x25 mg, and Apaurin when necessary. She denied any hereditary diseases. She had allergy to potatoes. She was a nonsmoker, and did not consume alcohol. Clinical examination verified a change of $5 \times 5 \mathrm{~cm}$ in diameter, with nodular appearance, red color, covered with necrotic deposits, fixed by a narrower base to the red part of the lower lip and its mucosa, pulling the complete lower lip backwards. Surgical excision in the 'W' pattern was performed. The histopathology results indicated a nodular type malignant melanoma (Breslow c. $40 \mathrm{~mm}$, Clark V, pT4b NxMx). At the time of histopathology report, the neck on the left side was clinically and by use of ultrasound positive. Cervical lymphadenectomy was performed on February 9, 2015, with supraomohyoid neck dissection on the right and radical neck dissection on the left side. The histopathology results showed the presence of metastatic lymph nodes in the left side of the neck and chronic reactive lymphadenitis on the right side of the neck. The patient was referred to oncology for conservative treatment according to the protocol for malignant melanomas. Currently, radiation treatment is under way.

\section{Discussion}

The incidence of cutaneous melanoma increased dramatically in the second half of the $20^{\text {th }}$ century, in contrast to the incidence of melanomas of oral mucosa, which has remained stable. In a review article, Chang et al. analyzed 84,836 cases of melanoma (in the USA) recorded in the period from 1985 to 1994 and localized in the skin (91.2\%), eyes (5.2\%), mucosa (1.2\%), and unknown primary localization (2.2\%) (Table 1$)^{26}$. In the study by Cheung et al., there were 659 cases of melanoma of the gastrointestinal tract: $53.6 \%$ anorectal (anal $31.4 \%$, and rectal $22.2 \%$ ), $32.8 \%$ oropharyngeal, $5.9 \%$ esophageal, $2.7 \%$ of the stomach, $2.3 \%$ of the small intestine, $1.4 \%$ of the gallbladder, and $0.9 \%$ of the colon ${ }^{27}$.

In the review article by Hicks and Flaitz, aggregated data are given from several articles related to
Table 1. Melanoma cases registered in the USA between 1985 and 1994

\begin{tabular}{|l|l|l|}
\hline Localization & $\%$ & $\mathrm{n}$ \\
\hline Skin & 91.2 & 77,370 \\
Mucosa & 1.3 & 1,103 \\
Head and neck & 55.4 & \\
Genital, women & 18.0 & \\
Anal/rectal & 23.8 & \\
Urinary & 2.8 & \\
Ocular & 5.2 & 4,411 \\
Uveal & 85.0 & \\
Conjunctival & 4.8 & \\
Other & 10.2 & \\
Unknown primary location & 2.2 & 1,952 \\
Regional metastasis & 43.0 & \\
Distant metastasis & 57.0 & \\
\hline
\end{tabular}

Table 2. Localization of 703 cases of melanoma of oral mucosa

\begin{tabular}{|l|l|l|}
\hline Localization & $\mathrm{n}$ & $\%$ \\
\hline Palate & 223 & 32 \\
Hard palate & 66 & 9 \\
Soft palate & 7 & 1 \\
Gingiva & 37 & 5 \\
Maxillary gingiva & 114 & 16 \\
Mandibular gingiva & 50 & 7 \\
Oral cavity & 82 & 12 \\
Buccal mucosa & 46 & 6 \\
Lips & 45 & 6 \\
Tongue & 18 & 3 \\
Base of the mouth & 11 & 2 \\
Uvula & 4 & $<1$ \\
\hline
\end{tabular}

melanomas of the mucosa of the head and neck, which include 703 cases of oral mucosa and 770 cases of sinonasal mucosa (Table 2$)^{4,26,27}$. In the review article by Mihajlović et al. ${ }^{36}$, data are cited from the American literature that $\mathrm{OM}$ are rare tumors with an annual incidence of 0.2 per million, that is, 1 case per 5 million people $^{37}$. The authors from South America provide a figure of $1.2 \mathrm{OM}$ cases per 10 million $^{38}$. OMs are more common in the Japanese population, accounting for $7.5 \%$ of all melanomas. Skin melanomas in Japan have a lower incidence than in the USA ${ }^{17,39}$. 
In the Republic of Croatia, no separate records are kept of melanomas of the oral mucosa ${ }^{40}$. In the Federation of Bosnia and Herzegovina, no records are kept of melanomas of the oral mucosa either, but records are kept of topographic diagnoses of oral carcinomas of the lips, tongue, mouth, salivary glands, tonsils and oropharyn ${ }^{41}$.

The prognosis of OM is poor, the 5-year survival is between $10 \%$ and $25 \%$, and the average survival is less than 2 years. For example, the 5 -year survival in patients with positive cervical lymph nodes is $16.4 \%$ and in patients with negative cervical lymph node findings $38.7 \%{ }^{8}$. OM more often affects men than women (2:1). In men, it occurs one decade earlier than in women. In men, it occurs most often in the decade from 51 to 60 years of age, and in women between 61 and 70 years of age ${ }^{8}$.

\section{Conclusion}

Primary melanomas of the oral mucosa are a very rare and aggressive malignancy. OM occurs from the existing melanin pigmentation, but some develop de novo. Dentists and family physicians, when examining pigmented oral mucosal lesions, should suspect OM in their differential diagnosis. Therefore, in every patient with oral pigmentation, oral biopsy specimen should be obtained as a diagnosis based solely on clinical appearance may be insufficient. Histopathologic diagnosis is the gold standard in the diagnosis of melanomas. About $80 \%$ of OMs are located in the region of the mucosa of the palate and maxillary gingiva.

\section{References}

1. Levanat S. Molekularni aspekti u etiologiji i patogenezi melanoma s posebnim naglaskom na "obiteljski" melanom. In: Šitum M, et al., editors. Melanom - udžbenik i atlas. Zagreb: HAZU - Medicinska naklada, 2016; p. 15-33. (in Croatian)

2. Holmstrom M, Lund VJ. Malignant melanomas of the nasal cavity after occupational exposure to formaldehyde. Br J Ind Med. 1991;48(1):9-11. PMID: 1993163

3. Axell T, Hedin CA. Epidemiologic study of excessive oral melanin pigmentation with special reference to the influence of tobacco habits. Scan J Dental Res. 1982;90(6):434-42. PMID: 6961509

4. Hicks MJ, Flaitz CM. Oral mucosal melanoma: epidemiology and pathobiology. Oral Oncol. 2000;36(2):152-69. PMID: 10745167
5. Virag M. Kirurško liječenje melanoma glave i vrata. In: Stanec S, et al., editors. Melanom. Zagreb: Medicinska naklada, 2006; p. 218-34. (in Croatian)

6. O’Brien CI, McNeil EB, McMahon JD, Pathak I, Lauer CS. Incidence of cervical node involvement in metastatic cutaneous malignancy involving the parotid gland. Head Neck. 2001; 23(9):744-8. DOI: $10.1002 /$ hed.1106

7. Ivkić M, Bedeković V. Značenje parotidektomije u kirurškom liječenju melanoma glave i vrata. In: Šitum M, et al., editors. Melanom - udžbenik i atlas. Zagreb: HAZU - Medicinska naklada, 2016; p. 116-7. (in Croatian)

8. Collins B, Abernethy J, Barnes L. Oral malignant melanoma. http://www.oralcancerfoundation.org/facts/rare/om/ 2010;1-16.

9. Breslow A. Thickness, cross-sectional areas and depth of invasion in the prognosis of cutaneous melanoma. Ann Surg. 1970;172(5):902-8. PMCID: PMC1397358

10. Clark WH Jr, From L, Bernardino EA, Mihm MC. The histogenesis and biologic behavior of primary human malignant melanomas of the skin. Cancer Res. 1969;29(3):705-27. PMID: 5773814

11. Prasad ML, Busam KJ, Patel SG, Hoshaw-Woodard S, Shah JP, Huvos AG. Clinicopathologic differences in malignant melanoma arising in oral squamous and sinonasal respiratory mucosa of the upper aerodigestive tract. Arch Pathol Lab Med. 2003;127(8):997-1002. DOI: 10.1043/1543-2165(2003)127< 997:CDIMMA>2.0.CO;2

12. Prasad ML, Patel SG, Huvos AG, Shah JP, Busam KJ. Primary mucosal melanoma of the head and neck: a proposal for micro staging localized, stage I (lymph node-negative) tumors. Cancer. 2004;100(8):1657-64. DOI: 10.1002/cncr.20201

13. Mücke T, Hölzle F, Kesting MR, Loeffebein DJ, Robitzky LK. Tumor size and depth in primary malignant melanoma in the oral cavity influences survival. J Oral Maxillofac Surg. 2009; 67(7):1409-15. DOI: 10.1016/j.joms.2008.12.021

14. Balch CM, Gershenwald JE, Soong SJ, Thompson JF, Atkins MB, Byrd DR, Buzaid AC, Cochran AJ, Coit DG, Ding S, Eggermont AM, Flaherty KT, Gimotty PA, Kirkwood JM, McMasters KM, Mihm MC Jr, Morton DL, Ross MI, Sober AJ, Sondak VK. Final version of 2009 AJCC melanoma staging and classification. J Clin Oncol. 2009;27(36):6199-206. DOI: 10.1200/JCO.2009.23.4799

15. Edge SB, Compton CC. The American Joint Committee on Cancer: $7^{\text {th }}$ edition of the AJCC Cancer Staging Manual and the future of TNM. Ann Surg Oncol. 2010;17(6):1471-4. DOI: $10.1245 / \mathrm{s} 10434-010-0985-4$

16. Barker BF, Carpenter WM, Daniels TE, Kahn MA, Leider AS, Lozada-Nur F, Lynch DP, Melrose R, Merrell P, Morton T, Peters E, Regezi JA, Richards SD, Rick GM, Rohrer MD, Slater R, Stewart JC, Tomich CE, Vickers RA, Wood NK, Young SK. Oral Mucosal Melanomas: the WESTOP Banff Workshop Proceedings. Western Society of Teachers of Oral Pathology. Oral Surg Oral Med Oral Pathol Oral Radiol Endod. 1997;83(6):672-9. PMID: 9195622 
17. Tanaka N, Amagasa T, Iwaki H, Shioda S, Takeda M, Obhasi $\mathrm{K}$, et al. Oral malignant melanoma in Japan. Oral Surg Oral Med Oral Pathol. 1994;78(1):81-90.

18. Lopuz-Graniel CM, Ochoa-Carrilo FJ, Meneses-Garcia A. Malignant melanoma of the oral cavity. Diagnosis and treatment experience in Mexican population. Oral Oncol. 1999;35 (4):425-30. https://doi.org/10.1016/0030-4220(94)90121-X

19. MacKie MR, et al., editors. Clinical Dermatology, $5^{\text {th }}$ ed. Oxford: Oxford University Press, 2003; p. 345-51.

20. Lipozenčić J, et al., editors. Dermatološka onkologija. Zagreb: Medicinska naklada, 2009; p. 111-23. (in Croatian)

21. Hartmann AA, Elsner P. Dermatologie für Zahnmediciner. Stuttgart-New York: GT Verlag, 1996; p. 202. (in German)

22. Šitum M, et al. Melanom - udžbenik i atlas. Zagreb: HAZU Medicinska naklada, 2016; p. 39-47. (in Croatian)

23. Zambal Z. Melanomalignom. In: Kogoj F, et al., editors. Bolesti kože - drugi dio. Zagreb: JAZU, 1971; p. 952-4.(in Croatian)

24. Devi P, Bhovi T, Jayaram RR, Walia C, Sing S. Malignant melanoma of the oral cavity showing satellitism. J Oral Sci. 2011;53(2):239-44. PMID: 21712630

25. Vučić M, Tomas D, Krušlin B. Patohistološki prognostički čimbenici melanoma. In: Šitum M, et al., editors. Melanom udžbenik i atlas. Zagreb: HAZU - Medicinska naklada, 2016; p. 174-7. (in Croatian)

26. Chang AE, Karnell LH, Menck HR. The National Cancer Database report on cutaneous and noncutaneous melanoma - a summary of 84,836 cases from the past decade. Cancer. 1998;83(8):1664-78. PMID: 9781962

27. Cheung MC, Perez EA, Molina MA, Jin X, Gutierrez JC, Franceshi $\mathrm{D}$, et al. Defining of the role of surgery for primary gastrointestinal tract melanoma. J Gastrointest Surg. 2008;12(4):731-8. DOI: 10.1007/s11605-007-0417-3

28. Bumber Ž, Janjanin S. Melanom sluznica glave i vrata. In: Stanec S, et al., editors. Melanom. Zagreb: Medicinska naklada, 2006; p. 337-42. (in Croatian)

29. Eisen D, Lynch PD. The Mouth - Diagnosis and Treatment. St. Louis: Mosby, 1998; p. 80-1.

30. Topić B. Melanotic pigmentation of oral mucosa. Acta Stomatol Croat. 2014;48(1):83-4.
31. Gazit D, Daniels TE. Oral melanocytic lesions: differences in expression of HMB-45 and S-100 antigens in round and spindle cells of malignant and benign lesions. J Oral Pathol Med. 1994;23(1):60-4. PMID: 8164154

32. Messina JL, Glass LF, Cruse CW, Berman C, Ku NK, Reintgen DS. Pathologic examination of the sentinel lymph node in malignant melanoma. Am J Surg Pathol. 1999;23(6):686-90. PMID: 10366151

33. Kernohan NM, Rankin R. S-100 protein: a prognostic indicator in cutaneous malignant melanoma. Histopathology. 1987; 11(12):1285-93. DOI: 10.1111/j.1365-2559.1987.tb01873.x

34. Puljiz Z, Šitum M. Kirurško liječenje melanoma. In: Štum M, et al., editors. Melanom - udžbenik i atlas. Zagreb: HAZU Medicinska naklada, 2016; p. 263-73. (in Croatian)

35. Bujas T, Pavić J, Prus A, Marušić Z, Baličević D. Primary oral malignant melanoma: case report. Acta Clin Croat. 2010;49(1): 55-9. PMID: 20635585

36. Mihajlović M, Vlajković S. Jovanović P, Stefanović V. Primary mucosal melanomas: a comprehensive review. Int J Clin Exp Pathol. 2012;5(8):739-53. PMID: 23071856

37. McLaughlin CC, Wu XC, Jemal A. Incidence of noncutaneous melanomas in the US. Cancer. 2005;103(5):1000-7. DOI: 10.1002/cncr.20866

38. Lourenco SV, Sangueza MA, Sotto MN, Bologna SB, Giacomo TB, Buim ME, et al. Primary oral mucosal melanoma: a series of 35 new cases from South America. Am J Dermatopathol. 2009;31(4):323-30. DOI: 10.1097/DAD.0b013e3181 $\mathrm{a} 0 \mathrm{~d} 37 \mathrm{c}$

39. Takagi M, Ishikawa G, Mori W. Primary malignant melanoma of the oral cavity in Japan, With special reference to mucosal malanosis. Cancer. 1974;34(2):358-70. PMID: 4853771

40. Zavod za zdravstvenu zaštitu Republike Hrvatske. Number of new cancer cases in Croatia by sex and primary site, 2008-2012. Bilten/Bulletin. 2013;37:15-6. (in Croatian)

41. Zavod za zdravstvenu zaštitu Federacije Bosne i Hercegovine. Number of new cancer cases by primary site in Federation Bosnia and Herzegovina 2000-2013. Registar za rak, 2014. (in Bosnian)

Sažetak

\section{MELANOM ORALNIH SLUZNICA - DVA PRIKAZA SLUČAJA I PREGLED LITERATURE}

\section{B. Topić, T. Mašić, S. Radović, I. Lincender i E. Mubic}

Oralni melanom $(\mathrm{OM})$ nastaje iz aktiviranih ili genski izmijenjenih epidermnih melanocita. Nema znanstvenih dokaza da se OM može vezati za fizikalne, kemijske i termičke iritacije ili druge rizične čimbenike usne šupljine. Prema podacima iz različitih zemalja na OM otpada od $0,2 \%$ do $7,5 \%$ (Japan) svih slučajeva melanoma kože i sluznica. Odnos muškaraca i žena za OM je 2:1. Oko 80\% slučajeva OM locirano je na sluznici tvrdog nepca i maksilarne gingive. U ovom radu prikazuju se dva slučaja OM gornje i donje usne u osoba ženskog spola u dobi od 62 i 59 godina. Opisane su dijagnoza, diferencijalna dijagnoza i terapija.

Ključne riječi: Melanom - patologija; Oralni tumori - dijagnostika; Oralni tumori - terapija; Prikazi slučaja 